\title{
Fuzzy-Logic Method and Sliding-Mode Control for Induction Motor
}

\author{
M. Sangeetha, M. Jasmine, S. Philomina
}

\begin{abstract}
Direct torque control (DTC) is known to generate fast and robust control for induction motor drives. Even though, in classical DTC, there exists a notable ripple in torque and flux during steady state, which can be reflected towards the speed response and generating undesirable acoustic noise. This paper introduces two approaches based on variable structure control (VSC) and fuzzy logic control (FLC) to mitigate steady state chattering problem while preserving the merits of DTC operation. The inverter is controlled directly on the basis of stator flux and the torque errors, by selecting most appropriate voltage vector from switching logic table. A comparative study is performed for the three control topologies including conventional DTC and simulation results are presented and discussed. It is concluded that SMC and intelligent control based technique provide better characteristics in steady state operation with regards to the conventional DTC.
\end{abstract}

Keywords:Induction motor drives, Direct torque control (DTC), Sliding mode control (SMC), Fuzzy logic control (FLC).

\section{INTRODUCTION}

Over the past decades, numerous control strategies have been developed for induction motor (IM) control to ensure high precision and less complexity of the Field Orient Control (FOC) technique [1], [2]. Direct Torque Control (DTC) can be treated as an alternative methodology to the FOC [3]. Both strategies were initially developed from field geometry principles. DTC is attractive due to its fast dynamics, simplicity, robustness against machine parameters and perturbations. However, conventional DTC associates with undesirable torque ripple which causes noise and higher losses to the drive. Current efforts are devoted to enhance the performance of DTC technique with regard to its inherent drawbacks. Various solutions with improved DTC can be identified in the literature. A modified DTC scheme for IM sensorless drive is presented in [4] based on space vector modulation technique.

Several attempts have been made to integrate VSC approach (also known also as sliding mode control (SMC)) with DTC control strategy as it is well suited for nonlinear systems with uncertainties [5].Observer designing by using sliding mode technique is an attractive choice, since it is

Revised Manuscript Received on August 22, 2019.

M.Sangeetha, Department of Electronics and Communication Engineering, Bharath Institute of Higher Education and Research, Chennai, Tamilnadu, India.E Mail - sang_gok@yahoo.com

M. Jasmine, Department of Electronics and Communication Engineering, Bharath Institute of Higher Education and Research, Chennai, Tamilnadu, India E Mail - rifriz@gmail.com

S. Philomina, Department of Electronics and Communication Engineering, Bharath Institute of Higher Education and Research, Chennai, Tamilnadu, India.E Mail -philomina.nov83@gmail.com robust and has fast dynamics. Sensor-less operation of IM drive is obtained by utilizing state observation topology in which sliding mode observer (SMO) is dominant [6-8]. Several implementations of SMO can be seen in literature [9-11]. Most of them are realized as speed observers. A sensorless DTC control algorithm based on SMO and improved IM model is presented in [12] which does not require speed information.

Further, recent attention is given to combine artificial intelligent control techniques with DTC scheme to obtain improved performance and enhanced robustness [10-13]. Unlike other intelligent algorithms, FLC is the simplest and does not require extensive mathematical analysis [11]. In [13] the authors, have incorporated proportional integral (PI) controller and FLC in steady state and transient operation respectively. The switching between two mechanisms is determined by the speed error. However, switching limits depend on the type of the FLC used and hence it makes the switching transitions more complicated. A practically feasible FLC based DTC scheme is presented in [13]. The proposed algorithm selects the bandwidth of the torque hysteresis controller such that it optimizes the torque ripple level. An approach to obtain optimum duty ratios of switching states using an analytical online algorithm, is described in [13] based on FLC because it reduces undesirable torque ripple significantly.

Recognizing the merits of employing SMC and FLC in DTC technique, this paper presents a comprehensive analysis of solution approach for induction motor drives. Direct torque and flux control are achieved with the help of SMC and intelligent fuzzy control methods. Both steady states and transient operation improvement are presented under proposed approaches.

\section{PROPOSED METHOD}

Complete derivation of the DTC principle for a symmetrical, balanced squirrel cage induction motor is presented in this section. The core idea behind the DTC strategy can be stated as simultaneous and decoupled control of stator flux and torque by properly adjusting the stator voltage[14],[16],[18].

\section{A. IM Model}

The Mathematical model of the induction motor stationary reference frame, with direct axis attached to the stator phase a which denoted by superscript ' $a$ ' and quadrature component denoted as superscript ' $p$ ' is given by [14]. 


$$
\begin{aligned}
\frac{d \psi_{s}^{\alpha}}{d t} & =-R_{s} i_{s}^{\alpha}+u_{s}^{\alpha} \\
\frac{d \psi_{s}^{\beta}}{d t} & =-R_{s} i_{s}^{\beta}+u_{s}^{\beta} \\
\frac{d \psi_{r}^{\alpha}}{d t} & =-R_{r} i_{r}^{\alpha} \vdash \omega_{r} \psi_{r}^{\beta} \\
\frac{d \psi_{r}^{\beta}}{d t} & =-R_{r} i_{r}^{\beta}+\omega_{r} \psi_{r}^{\alpha} \\
\frac{d \omega}{d t} & =\frac{1}{J}\left\lceil T_{e}-T_{L}\right\rceil \\
\omega_{r} & =n_{p} \omega
\end{aligned}
$$

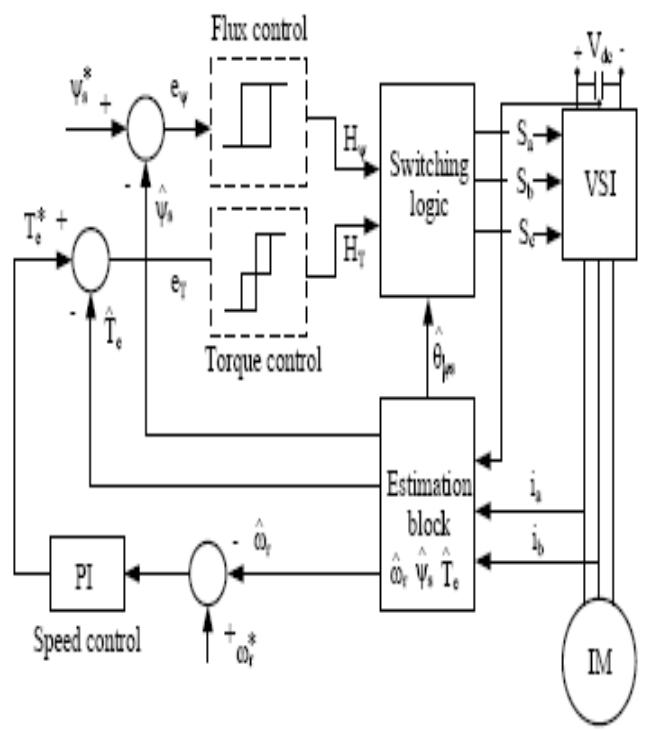

Figure 1. Block diagram of conventional DTC (CDTC)

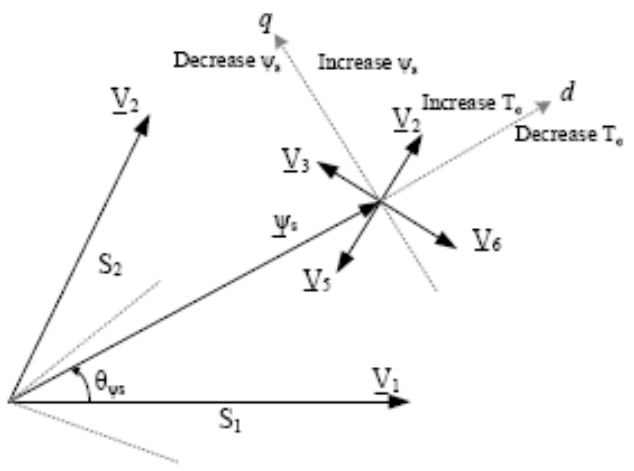

Figure2. Control principle of conventional DTC

\section{B. DTC Using Switching Table}

The fundamental idea behind the DTC concept is to achieve decoupled control of both flux and torque by properly selecting the stator voltage analogous to the torque and flux error. A block diagram of CDTC based induction motor drive is shown in Fig.1 [1]. As depicted in the Fig. 1, a CDTC drive comprised of mainly four modules: a state observer, the stator flux controller, the torque controller and the switching strategy.

\section{DTC VIA SLIDING MODE CONTROL}

SMC is used to achieve a robust and fast dynamic performance for IM drive. SMC enforces the system to stay on the pre-defined sliding surface by adaptively adjusting the structure of the controller. Fig. 3 shows the proposed integral type sliding mode DTC (SMDTC) scheme. The drive employs Speed control $+m * r$ a PI speed controller and stator flux, torque and speed observers. The control objective of the drive is to control the stator flux magnitude and the torque of the machine[13],[15],[17].

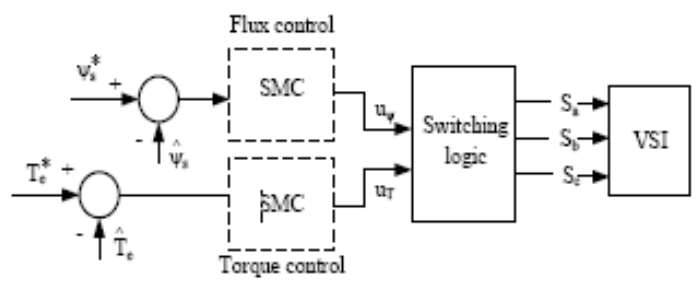

Figure 3. SM based control scheme for DTC

\section{FLC IN DTC}

In conventional DTC, the higher ripples in torque and flux compose a real problem [19],[20]for IM drive applications. In this section a fuzzy logic (FL) approach is proposed in order to reduce an inherent problem in classical DTC. Target is achieved by replacing the hysteresis controllers in classical method from two FLCs with one in stator flux control loop and the other one in electromagnetic torque control as depicted in Fig. 4.

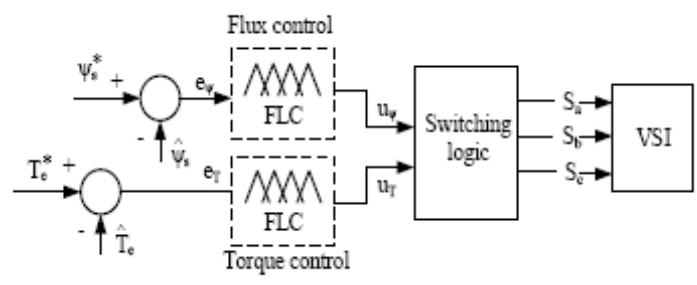

Figure 4:Fuzzy logic DTC

\section{SIMULATION RESULTS}

In order to analyze the performances of sliding mode and fuzzy logic in DTC, example simulations were performed using Matlab. The Parameter values of the induction motor used for the simulation are given in the Table I. Speed and stator flux references used for the simulation are $150 \mathrm{rad} / \mathrm{s}$ and $0.9 \mathrm{~Wb}$ respectively. Reference speed step is applied to the controller at $\mathrm{t}=0.5 \mathrm{~s}$ and a PI controller is used as the speed controller in order to generate the electromagnetic torque reference trajectory. At $\mathrm{t}=1 \mathrm{~s}$, a load torque of $8 \mathrm{Nm}$ is given to the motor. 

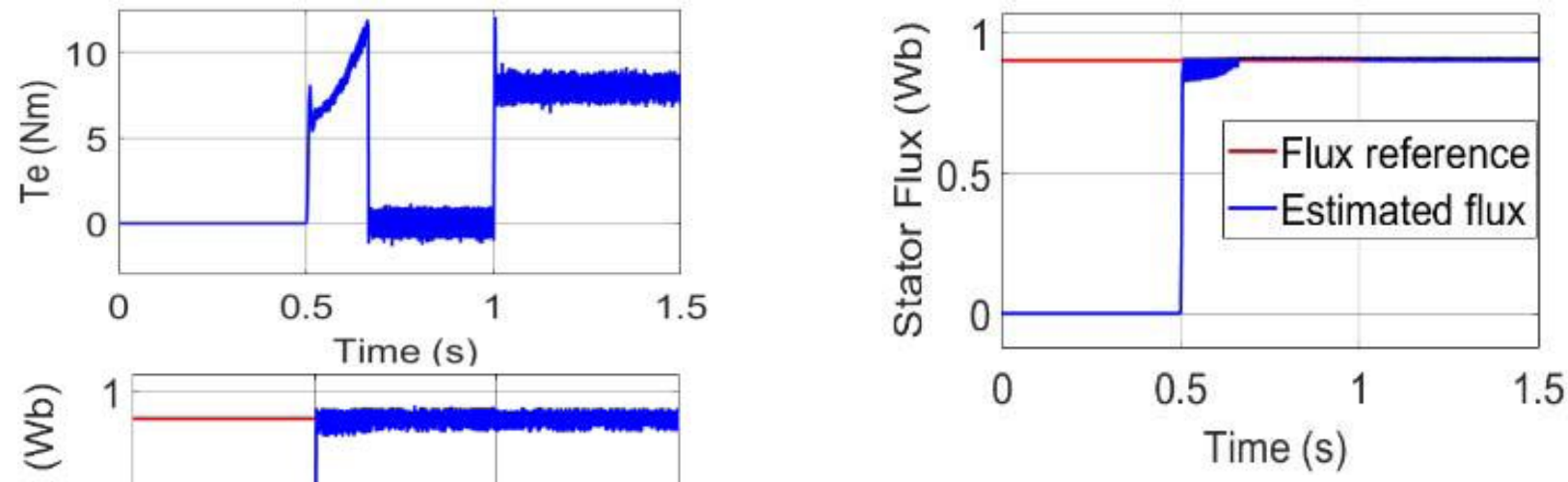

Figure 5. Electromagnetic torque and stator flux response. (a) Te CDTC (b)Flux CDTC (c) Te SMDTC (d) Flux SMDTC (e) Te FLDTC (f) Flux FLDTC

\section{PERFORMANCE UNDER VOLTAGE SAG}

The behavior of these three controllers under voltage sag condition is analyzed in this section. A $50 \%$ voltage sag is applied to the each driver after they attained steady state operation. Drivers experience a lower voltage for $0.2 \mathrm{~s}$ period starting from $\mathrm{t}=0.8 \mathrm{~s}$. Fig. 8 demonstrates the torque and speed response of each controller.
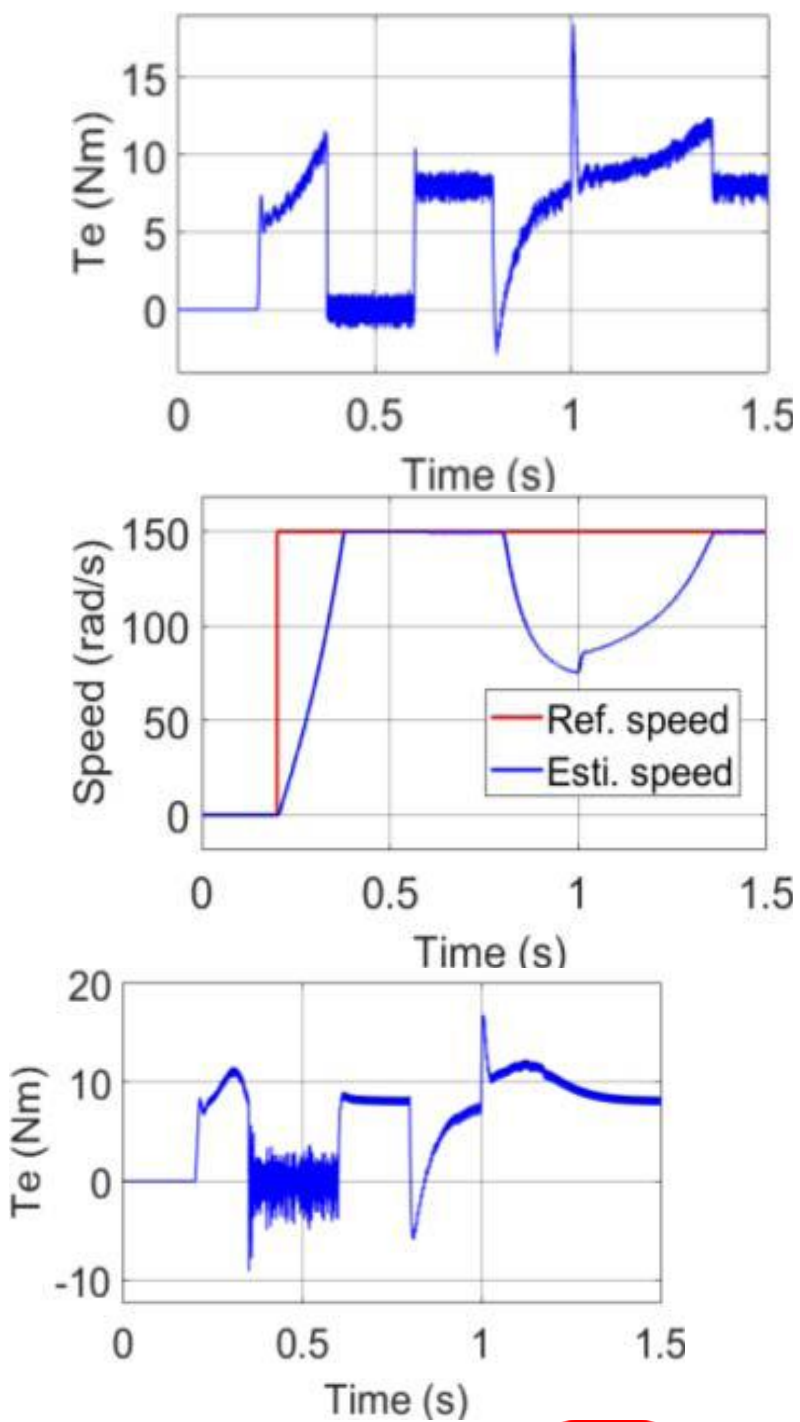

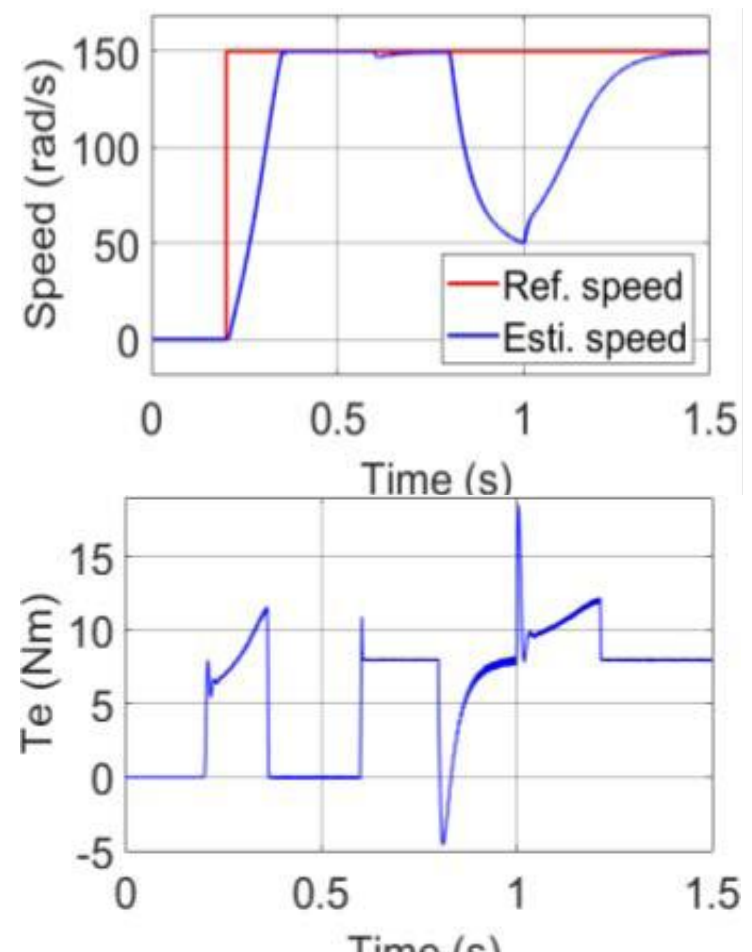

Time (s)

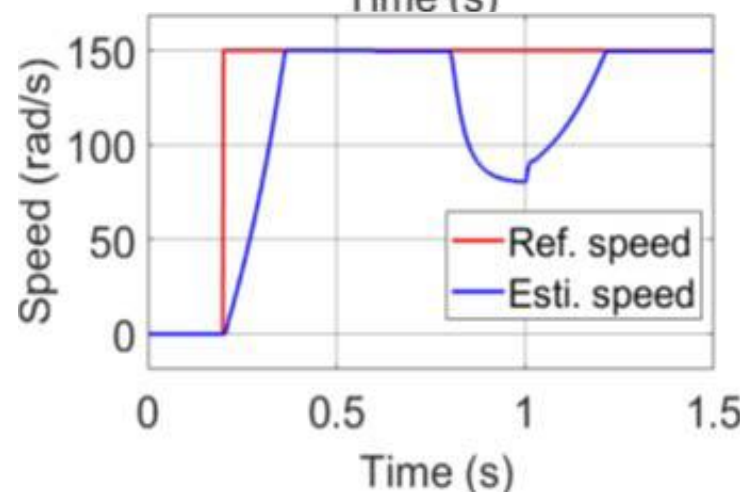

Figure 6. Electromagnetic torque and speed response under a voltage sag condition (a) Te CDTC (b) Speed CDTC (c) Te SMDTC (d) Speed SMDTC (e) Te FLDTC (f) Speed FLDTC

As shown in Fig. 6, torque and speed drop when the voltage dip occurred. Soon after the voltage drop is cleared, torque increases to provide acceleration torque to the IM. Torque recovery times of CDTC, SMDTC and FLDTC controllers were observed as, $1.36 \mathrm{~s}, 1.34 \mathrm{~s}$ and $1.21 \mathrm{~s}$ respectively. Hence, according to the results obtained, SM and FL based DTC drives have better response over CDTC under voltage sag conditions.

\section{CONCLUSION}

This paper proposes a design approach to integrate the SM and FL control strategies to enhance the performances of DTC drives. FLC and the SMC are used to replace the hysteresis controller of CDTC algorithm. The simulation results demonstrate that two strategies (SMC and FLC) have a significant impact on performances when compared to the CDTC drive. During the steady-state, proposed controllers operate with a lower ripple in electromagnetic torque and stator flux and FLDTC has the lowest ripple among them. In transient stage, FLDTC offer better dynamic performances with regard to the torque and speed transients. These two approaches can be further extended towards designing a state observer for DTC. A complete variable structure and fuzzy control based robust and accurate solution can be developed for sensorless induction machine operation.

\section{REFERENCES}

1. Kongkham, D. \& Sundararajan, M. 2019, "Distributed wideband sensing method for faded dynamic spectrum access", International Journal of Innovative Technology and Exploring Engineering, vol. 8, no. 10, pp. 4309-4312.

2. Balaji, S., John Paul Praveen, A. \& Mohanraj, R. 2019, "Recognizable proof and analysis of palm print in biometric authentication system using bayes techniques", International Journal of Innovative Technology and Exploring Engineering, vol. 8, no. 9 Special Issue 3, pp. 1126-1129.

3. Kavitha, G., Priya, N., Velvizhi, R. \& Allin Geo, A.V. 2019, "Parallel computation in correspondence and signal processing", International Journal of Innovative Technology and Exploring Engineering, vol. 8, no. 9 Special Issue 3, pp. 1136-1139.

4. Hema, R., Sundararajan, M. \& Balaji, S. 2019, "Smartphone control robot with automatic firing gun", International Journal of Innovative Technology and Exploring Engineering, vol. 8, no. 9 Special Issue 3, pp. 625-627.

5. Kaliyamurthie, K.P., Sundar Raj, B., Velvizhi, R. \& Shanmugapriya, K. 2019, "Dual band paper substrate CPW antenna for wireless applications", International Journal of Innovative Technology and Exploring Engineering, vol. 8, no. 9 Special Issue 3, pp. 605-608.

6. Geo, A.V.A., Arunachalam, A.R., Michael, G. \& Elankavi, R. 2019, "Evaluating architecture using compact modalities", International Journal of Innovative Technology and Exploring Engineering, vol. 8, no. 9 Special Issue 3, pp. 836-838.

7. Theivasigamani, S., Jeyapriya, D. \& Anita Davamani, K. 2019, "Anamoly analyzing and exploring for wireless sensor networks", International Journal of Innovative Technology and Exploring Engineering, vol. 8, no. 9 Special Issue 3, pp. 1116-1118.

8. Jeyapriya, D., Theivasigamani, S., Velvizhi, R. \& Nandhini, P. 2019 "Program detection in wireless feeler networks", International Journal of Innovative Technology and Exploring Engineering, vol. 8, no. 9 Special Issue 3, pp. 1194-1195.

9. Gowri Sankaran, B., Karthik, B. \& Vijayaragavan, S.P. 2019, "Image compression utilizing wavelet transform", International Journal of Innovative Technology and Exploring Engineering, vol. 8, no. 10, pp. 4305-4308.

10. Gowri Sankaran, B., Karthik, B. \& Vijayaragavan, S.P. 2019, "Weight ward change region plummeting change for square based image huffman coding", International Journal of Innovative Technology and Exploring Engineering, vol. 8, no. 10, pp. 4313-4316

11. Hema, R., Sundararajan, M. \& Balaji, S. 2019, "Smartphone control robot with automatic firing gun", International Journal of Innovative Technology and Exploring Engineering, vol. 8, no. 9 Special Issue 3, pp. 625-627.

12. Rangaswamy, K. \& Rajabhushanam, C. 2019, "Congestion control in wireless network using TCP friendly rate control (TFRC)", International Journal of Recent Technology and Engineering, vol. 8 , no. 2 Special issue 3, pp. 1598-1602.

13. Tamil Selvan, S. \& Sundararajan, M. 2019, "Performance Parameters of 3 Value 8t Cntfet Based Sram Cell Design Using H-Spice", International Journal of Recent Technology and Engineering, vol. 8, no. 2 Special issue 5, pp. 22-27.

14. Vinoth, V.V. \& Kanniga, E. 2019, "Steganographical techniques in hiding text images - system", International Journal of Recent Technology and Engineering, vol. 8, no. 2, pp. 6535-6537.

15. Saravana, S., Balaji, S., Arulselvi, S. \& John Paul Praveen, A. 2019 "Reliable power quality monitoring and protection system", International Journal of Innovative Technology and Exploring Engineering, vol. 8, no. 9 Special Issue 3, pp. 644-645.

16. Sundaramoorthy, A. \& John Wiselin, M.C. 2019, "Single patch antenna with multiple feed", International Journal of Innovative Technology and Exploring Engineering, vol. 8, no. 9, pp. 1743-1747.

17. Velavan, R., Bharanidharan, S. \& Sheeba, B. 2019, "EMF pollution Causes, effects and protection", International Journal of Innovative Technology and Exploring Engineering, vol. 8, no. 9 Special Issue 3, pp. 1166-1168. 
18. Veer, R.A., Arulselvi, S. \& Karthik, B. 2019, "Construction of ensemble square classification approaches in MIMO OFDM", International Journal of Engineering and Advanced Technology, vol. 8, no. 5, pp. 2039-2041.

19. Agitha, W. \& Kaliyamurthie, K.P. 2019, "Improved energy efficient in WBAN using MAC with cloud computing", International Journal of Innovative Technology and Exploring Engineering, vol. 8, no. 8, pp. 2405-2408.

20. Kastro, G.G. \& Wiselin, M.C.J. 2019, "Design and analysis of stub loaded resonator", International Journal of Recent Technology and Engineering, vol. 8, no. 1 Special Issue4, pp. 272-283.

\section{AUTHORS PROFILE}

M.Sangeetha Associate Professor, Department of Electronics and Communication Engineering, Bharath Institute of Higher Education and Research, Chennai, India.

M. Jasmine, Assistant Professor, Department of Electronics and Communication Engineering, Bharath Institute of Higher Education and Research, Chennai, India.

S. Philomina, Assistant Professor, Department of Electronics and Communication Engineering, Bharath Institute of Higher Education and Research, Chennai, India. 